\title{
Many species, including locally rare species, are important for function of mutualist networks
}

Dylan Simpson ${ }^{1}$, Lucia Weinman ${ }^{1}$, Mark Genung ${ }^{1}$, Michael Roswell ${ }^{1}$, Molly MacLeod ${ }^{1}$, and Rachael Winfree ${ }^{1}$

${ }^{1}$ Rutgers University

December 13, 2021

\section{Hosted file}

Simpson et al - Many bee species, including rare species, are important for function of entire plant-po available at https://authorea.com/users/381800/articles/497707-many-species-includinglocally-rare-species-are-important-for-function-of-mutualist-networks

\section{Hosted file}

Simpson et al - Supplement.pdf available at https://authorea.com/users/381800/articles/ 497707-many-species-including-locally-rare-species-are-important-for-function-ofmutualist-networks 